Viazova, N.V. (1998). Obuchenie monologicheskoi rechi na osnove teksta (Вязовова Н. В. Обучение монологической речи на основе текста). Vestnik Tambovskogo universiteta.№ 3. Print.

Zaitseva, I.A. (2007). Tekhnologia urovnevoi differentsiatsii kak sredstvo formirovania professionalnoi inoyasychnoi kommunikativnoi kompetentnosti studentov tekhnicheskogo vuza (Зайцева И. А. Технология уровневой диффреренциации как средство формирования профессиональной иноязычной коммуникативной компетентности студентов технического вуза). Diss. Samara. Print.
Zahalnoyevropeiski rekomendatsii z movnoii ostity: vyvchennia, vykladannia, otsiniuvannia (2003). (Загальноєвропейські рекомендації 3 мовної освіти: вивчення, викладання, оцінювання). Kyiv: Lenvit, Print.

Zhigalik, M.A. (2008). Differentsirovannyi podhod $k$ razvitiiu poznavatelnoi aktivnosti starshikh doshkolnikov sredstvami nagliadnogo modelirovaniia (Жигалик М. А. Дифференцированный подход к развитию познавательной активности старших дошкольников средствами наглядного моделирования ). Diss. Velikii Novgorod. Print.

\title{
DIFFERENTIATED TEACHING OF ENGLISH ORAL MONOLOGIC PRODUCTION TO LAW STUDENTS: OBJECTIVES AND CONTENT
}

\author{
Olena Tkachenko \\ Department of Teaching Methodology of Ukrainian and Foreign Languages and Literatures, Institute of Philology, Taras \\ Schevchenko National University of Kyiv \\ Tetiana Druzhchenko \\ Department of Teaching Methodology of Ukrainian and Foreign Languages and Literatures, Institute of Philology, Taras
} Schevchenko National University of Kyiv

\section{Abstract.}

Background: Among numerous issues of differentiated teaching, the problem of building competence in oral monologic production in Law students - considering the level of independence and knowledge of students - has not been studied in depth yet. This causes difficulties for providing qualitative foreign language (FL) education to Law majors who have not attained the appropriate level in FL communicative competence in conditions of homogenous training groups.

Purpose. The article aims to define objectives and content of differentiated teaching of English oral monologic production to Law students.

Results. The paper has proved that Law students shall be able to make up monologues in the genre of report-presentation of the three functional types, i.e. narration, description, reasoning (justification and retraction), having mastered their lingual and extralingual peculiarities. Lexico-semantic and grammatical characteristics of each of the three functional types of monologues have been defined. The report-presentation is determined as a short report up to ten minutes (based on well-studied sources of information) supported with the demonstration of the objects, which are the subject matter of the report. The triad of the categories of monologic production is essential when teaching law students, namely those of the quantity of information, the quality of information and the means of information submission.

To enhance English monologic production skills in Law students, individual and psychological characteristics of learners, their cognitive needs, communicative abilities, motivation, independence, professional mindset as well as professional activity should be taken into account.

Discussion. A set of criteria to evaluate the outcomes of the learning process and assess individual progress of students has been developed. The following criteria as for the assessment of spontaneous oral production were defined: the ease of production, the scope of the utterance, the meaningful completeness and the level of realization of the communicative intent, the contextual and grammatical integrity, linguistic literacy. Prepared oral production was evaluated based on the criteria of informativeness, adherence to the compositional peculiarities of a certain functional type of a report, the contextual completeness and the level of realization of communicative intent, the contextual and grammatical integrity, linguistic literacy). The category of the quantity of information provides for the integration of monologic production with professional knowlege of a lawyer who has to be able to use both: declarative and procedural knowledge - facts, data, models as well as the algorithms of solving professional tasks. While developing monologues, a Law student shall represent the sufficient amount of information for the theme exposure, for the justification or retraction of their thoughts. The category of quality of information in the lawyer's speech is regulated by the criteria of relevance and novelty. According to the category of the means of information submission, the student has to choose those verbal means of communication, which can reflect the author's idea, can be appropriately understood by native speakers, correspond to the style of communication, provide its cohesion and coherence.

Keywords: objectives and content of teaching, oral monologic production, differentiated teaching, report-presentation, individual results, skills and abilities of students, training of students.

Vitae:

Tetiana Druzhchenko, PhD, Assistant Professor, Department of Teaching Methodology of Ukrainian and Foreign Languages and Literatures, Institute of Philology, Taras Schevchenko National University of Kyiv, Ukraine. Her area of research interests includes teaching English speaking to Law students based on differentiated approach.

Correspondence: imagine_tanya@ukr.net 
Olena Tkachenko, PhD in Pedagogical Studies, Associate Professor, Department of Teaching Methodology of Ukrainian and Foreign Languages and Literatures, Institute of Philology, Taras Schevchenko National University of Kyiv, Ukraine. Her area of research interests includes the problem of pedagogical stimulation of students' educational and cognitive activities in educational establishments of Ukraine.

Correspondence: alena.yarkova22@gmail.com

ВІРА ПОНОМАРЬОВА, АЛІНА СІКОРСЬКА (м. КИЇВ)

УДК=371:811.11

ORCID: 0000-0003-1880-4691

ORCID: 0000-0002-6980-6366

\section{КОМПЛЕКС ВПРАВ ДЛЯ ФОРМУВАННЯ АНГЛОМОВНИХ ПРОСОДИЧНИХ НАВИЧОК У ГОВОРІННІ УЧНІВ СТАРШИХ КЛАСІВ ЗАГАЛЬНООСВІТНІХ ШКІЛ}

У статті визначено роль володіння просодичними навичками усного англійського мовлення описано основні шляхи їхнього фрормування в учнів старших класів загальноосвітніх шкіл. Проаналізовані роботи вітчизняних та зарубіжних учених із визначення компонентного складу просодичної компетентності учнів, які вивчають англійську мову в старших класах загальноосвітніх шкіл. Пильну увагу авторів привертає аналіз особливостей реалізації кожного компоненту англійської просодичної складової, схожість та відмінність реалізації кожного з них в англійській та українській мовах та запропоновано комплекс вправ та завдань для удосконалення володіння англійською просодичною складовою учнями старших класів загальноосвітніх шкіл.

Ключові слова: навчання просодії, інтонація, просодична компетентність учнів, просодична складова англійського мовлення, просодичний компонент якості вимови.

Постановка проблеми та актуальність дослідження. Згідно з чинними програмами для загальноосвітніх навчальних закладів учні старшої школи мають володіти не лише граматичним і лексичним аспектами мови, але й уміти фонетично правильно оформлювати своє власне мовлення. Мета навчання фонетики полягає у тому, щоб закласти у довготривалу пам'ять учнів нормативний склад вимовних елементів (фонем та інтонем) та автоматизувати їх відбір і комбінування. У процесі оволодіння іноземної мови відповідні навички повинні постійно вдосконалюватися і досягти свого найвищого рівня до моменту закінчення навчання у загальноосвітньому навчальному закладі. Натомість спостереження за навчальним процесом свідчать про те, що рівень володіння просодичною компетентністю учнів старшої школи до моменту закінчення навчання $€$ досить низьким, спеціальні вправи та завдання для удосконалення просодичних навичок учнів в підручниках майже не представлені, що зумовлює актуальність розробки якісно нових підходів до формування просодичних навичок в говорінні учнів старших класів.

Аналіз останніх досліджень. Просодія $€$ невід'ємним складником процесу говорін- ня, адже просодично-інтонаційні компоненти, взяті у комплексі, не лише допомагають передавати думки, але і додають психо-емоційне забарвлення висловлюванню, викликають зацікавленість комунікаторів та реципієнтів адресованою до них інфрормацією (Ковалевська, 2011).

Вивчення просодії зазнало помітних змін за останній час серед авторів з прикладної лінгвістики, а поняття «просодія» отримало велике поширення й водночас різне тлумачення (А. М. Антипова, В. А. Васильєв, Л.В.Величкова, М.П.Дворжецька, Ю.О.Дубовський, А. А. Калита, Т. М. Корольова, В. Ю. Паращук, Н. Д. Світозарова, М. О. Соколова, R. Lado, K. Pike, D. Bolinger, D. Chrystal). 3 метою покращання інтонаційної виразності мовлення створено спеціальні комп'ютерні програми для аналізу звукових текстів та навчання фонетики («TONI» та «Plato» J A Maidment, «Speech analyzer» T. Taguchi, «Praat» P. Boersma та D. Weenink, «WASP» M. Huckvale, «Sheep \& ship» T. Bowyer), наразі здійснено можливість успішної перевірки усного мовлення за допомогою застосування комп'ютерних систем колективами розробників мовних тестів. Зокрема, М. Канале та М. Свейн (Canale, Swain) відзначають, що саме по собі усне мовлення 
$€$ складним явищем, та виділяють інтонаційні навички як необхідну умову оволодіння умінням говорити іноземною мовою.

На нашу думку, питання розробки ефективних шляхів формування просодичної складової англійського усного мовлення $€$ конче актуальним, про що свідчить ціла низка факторів. По-перше, тестування усного мовлення стає більш об'єктивним і досконалим, тому 3 введенням нових вимог до усних випробувань із застосуванням комп'ютерних програм, усне мовлення не буде залишатися поза увагою тестологів, а просодія як складова будь-якого усного мовлення також буде включена до обов'язкових показників володіння усним мовленням. По-друге, важливим фрактором, який заслуговує особливої уваги в роботі над формуванням просодичних навичок АМ учнів старших класів $€$ аналіз рівня їхнього психофізіологічного розвитку, який дає нам можливість виділити основні напрямки в роботі.

Отже, започаткувати дискусію, представити основні теоретичні положення, викласти власні думки та запропонувати комплекс вправ для формування просодичних слухо-вимовних навичок учнів старшої школи є метою цієї статті. Почнемо із аналізу теоретичних джерел із проблеми.

Виклад основного матеріалу. Вирішуючи питання розробки підходів до формування просодичної складової англійського мовлення учнів старших класів, важливим є визначення лінгвістичних особливостей просодичної складової англійського мовлення вітчизняними та зарубіжними вченими.

Так, А. М. Антипова представляє два діаметрально протилежні погляди щодо понять «просодія» та «інтонація», розмежовуючи їх та розглядаючи їх як багатокомпонентну єдність. Компоненти інтонації характеризуються як «складний комплекс просодичних елементів» і фактично ототожнюються з просодією, яку розуміють як систему вимови наголошених і ненаголошених, довгих і коротких складів у висловлюванні (Антипова 1980).

Значна кількість зарубіжних фонетистів обмежують формальне визначення просодії виключно тональними змінами, проте П. Роуч пропонує визначення інтонації на двох рівнях: 1) у вужчому значенні, це коливання мелодики голосу мовця для передачі або зміни значення; 2) у ширшому розумінні інтонація є інтегра- цією просодичних компонентів, таких як зміни якості голосу, темпу та гучності мовлення (Roach 2012).

Водночас В. Ю. Паращук зазначає, що фронетисти дійшли згоди, що на рівні сприйняття «просодія» як комплексна єдність, сорормована значними варіаціями 1) тону, 2) гучності (сили вимовляння) і 3) темпу (тобто швидкості мовлення та розстановки пауз), називається інтонаційним офрормленням висловлювання, або інтонацією та співвідносить поняття просодії та інтонації як більш загальне (просодія) та один із компонентів загального (інтонація). (Паращук 2009: 191).

Мовлення без інтонації, коли склади вимовляються на одному тональному рівні без пауз та змін швидкості і гучності, звучить як роботизований потік слів, позбавлений змісту. Саме інтонація наповнює висловлення змістом і має важливе значення в комунікації. На сьогодні відсутня єдина класифікація функцій інтонації, проте є багато спільного в підходах різних вчених.

Д. Крістал (Crystal 2003) узагальнює функції інтонації за наступними критеріями:

1) Емоційна функція передає широке коло оцінних значень висловлювань мовця, як-от збудження, нудьгу, здивування, привітність, замкненість, тощо. Тут інтонація разом з іншими просодичними та паралінгвістичними засобами забезпечує основу всіх видів голосової емоційної виразності.

2) Граматична функція позначає граматичні контрасти. Ідентифрікація меж речення чи його частини часто залежить від контурів висоти звучання, які розділяють висловлювання. Такі специфічні протиставлення, як запитання та ствердження, схвалення чи заперечення, також залежать від інтонаційного оформлення. У багатьох мовах у процесі комунікації відбувається чітке розрізнення між «запитанням» та «розповіддю» наступним чином: She's here, isn't she? (де підвищення тону $є$ розмовним еквівалентом знаку запитання) та She's here, isn't she! (де низхідний тон виражає окличний знак).

3) Функція інформативного структурування реалізується у розмежуванні між новою та вже відомою адресатові інформацією. У випадку, якщо хтось повідомляє I saw a BLUE car, з максимальним інтонаційним виділенням blue, то мається на увазі, що в адресанта пе- 
ред цим запитали, якого кольору автомобіль він бачив; у той час, як наголос на I апелює до попередньо поставленого питання про те, яка особа була задіяна в цій ситуації. Було б дуже дивно запитати Who saw a blue car? та отримати у відповідь / saw a BLUE car!

4) Текстова фуункція допомагає пов'язати довші відрізки тексту. Просодична зв'язність простежується у тому, як окремі відрізки інформації набувають характерного мелодійного офрормлення. В процесі переходу диктора від одного пункту новин до наступного, рівень висоти тону підвищується, потім поступово спадає і в кінці голос мовця досягає відносно низького рівня.

5) Психологічна ффункція організовує мову в одиниці, легші для сприйняття та запам'ятовування, адже розподілене на ритмічні відрізки мовлення легше сприймається (Crystal 2003).

На думку П. Роуч комунікативно актуальними функціями інтонації $є$ функція: 1) відношення для вираження емоцій та ставлення мовця; 2) експресивності для виділення складу або слова, яке сприймається як найважливіше в інтонаційній групі; 3) граматична для розмежування різних синтаксичних структур; 4) дискурсивна для розмежування нової та відомої інфрормації (тема-рема) та передачі інфрормації про те, яка зворотна реакція очікується (Roach, 2012).

Оскільки компонентами інтонації є мелодика мовлення, наголос, темп, ритм, паузація та тембр, розглянемо кожний компонент окремо. Перший компонент - мелодика мовлення.

О. С. Ахманова визначає мелодику мовлення або мелодію як модуляції висоти основного (інтонаційного) тону при промовлянні фррази, що здійснюються за рахунок різного ступеню напруги голосових зв'язок (Akhmanova, 2007). Як рух основного тону голосу (підвищення і пониження), мелодика створює тональний контур висловлювання та його частин і, таким чином, зв'язує та членує мовлення. Таким чином, суттєве пониження тону вказує на завершеність повідомлення або якоїсь його відносно самостійної частини. I навпаки, підвищення говорить про незавершеність думки, про те, що потрібно чекати продовження, або, при іншому мелодійному малюнку, про те, що це питання, а не твердження (Теоретична, 2015, p. 83).
М. А. Соколова, серед параметрів мелодики, виділяє три найвиразніших, а саме: 1) напрям мелодики; 2) мелодійний рівень; 3) мелодійний діапазон (Соколова, 2004).

В мовленні не всі наголошені склади є рівноцінно значущими. Один із складів важливіший за інші, він формує ядро або центр інтонаційного контура. Формально, ядро можна описати як сильно наголошений склад, який зазвичай $€$ останнім наголошеним складом інтонаційного контура й позначає суттєву зміну напрямку мелодики / тону, тобто коли тон рухається чітко вгору чи вниз. Ядерний тон одна з найважливіших частин інтонаційного контура, без якого останній не може існувати (там само).

3 точки зору практики навчання інтонації англійської мови, доцільніше зупинитися на шістьох найбільш уживаних ядерних тонах, асаме: низькому низхідному, низькому висхідному, високому низхідному, високому висхідному, низхідно-висхідному та висхідно-низхідному. Р. Кінгдом ці тони називає кінетичними, тому що висота голосу змінюється в тому чи іншому напрямку під час тривалості всього тону. Услід за вченим також виокремлють статичні тони: високий та низький, в яких висота голосу залишається незмінною протягом усієї тривалості тону (Kingdom, 1958).

Англійський Low Fall (низький низхідний) в ядрі починається дещо вище, ніж середня шкала, і зазвичай сягає найнижчого рівня тону. Low Fall вживається у спокійному, емоційно незабарвленому мовленні, а також надає висловлюванню мовця відтінку нейтральної, спокійної закінченості, визначеності й рішучості. Фрази, в яких ужито даний ядерний тон, звучать категорично, спокійно, нейтрально, завершено (Паращук, 2009, р. 114).

High Fall (високий низхідний) в ядрі починається дуже високо й зазвичай досягає найнижчого рівня. Такий ядерний тон забезпечує високий ступінь виділення інформації, використовується в емоційно забарвленому мовленні, особливо при запереченні чи протиставленні, з метою привернути увагу слухача до виділеного слова. Використання цього тону надає відтінку особистого ставлення, зацікавленості та теплоти. High Fall звучить жваво і зацікавлено, окрім цього, він може бути дуже емоційним та дружнім (там само). 
Low Rise (низький висхідний), починається 3 найнижчого рівня та досягає середньої висоти звучання (у випадку, якщо його вжито на ядрі). Тут закладено відчуття незавершеності думки, вагання. Такі фррази звучать не категорично, здивовано, заспокійливо та можуть вказувати на те, що розмова продовжуватиметься. Low Rise вживається: a) у розповідних реченнях для вираження докору, іронії, вибачення, задоволення, невпевненості, прохання, звертання; б) у загальних питаннях (загальне питання починається з допоміжного, або модального дієслова, яке в цьому випадку звичайно має фрразовий наголос і вимовляється за повною формою вимови) (там само).

High Rise (високий висхідний) в межах ядра підіймається від середнього до високого рівня шкали за умови відсутності заядерного безакцентного закінчення. Якщо ж є склади, котрі слідують за ядром, останнє вимовляється на дещо вищому рівні, а ненаголошені склади поступово йдуть догори. High Rise виражає активне бажання адресанта отримати певну інформацію. За допомогою цього тону оформлюються перепитування, прохання повторити чи запит додаткових даних, або ж із наміром перевірити, чи правильно була сприйнята інформація. Інколи цей тон використовується, щоб зазначити продовження акту комунікації (там само).

Fall-Rise (низхідно-висхідний) відносять до складних тонів, оскільки він репрезентує поєднання двох тонів: або низького низхідного в комбінації із низьким висхідним, або високого низхідного, за яким іде низький висхідний. Низхідна частина позначає ідею, яку мовець прагне підкреслити, а висхідна частина додає певну інформацію до цієї ідеї. Уживання даного тону вказує на те, що якась інфрормація, заздалегідь відома обом учасникам акту комунікації, зумисне замовчується. Досить часто використовується у стверджувальних реченнях та наказах. Стверджувальні конструкції з Fall-Rise виражають корегування сказаного кимось іншим, або протиріччя попередньо сказаному чи застереження. Накази, вимовлені цим тоном, звучать благально. Привітання та прощальні побажання звучать приємно та дружньо, якщо для них використовується Fall-Rise (там само).

Rise-Fall (висхідно-низхідний) $€$ також складним тоном. У складах, які вимовляються 3 Rise-Fall, голос спочатку підіймається від дещо низького до високого рівня, а потім швидко спадає до дуже низького. Даний тон позначає глибокі враження мовця (як позитивні, так і негативні). Цей тон використовують у твердженнях та запитаннях, які звучать здивовано, кидають виклик, заперечують відповідальність (там само).

Порівнюючи англійське та українське мовлення, маємо звернути увагу на наступні відмінності. Інтонація в обох мовах характеризується наявністю спадного, висхідного та рівного тонів. В англійській мові спадний тон $є$ зниженням тону голосу на наголошених складах, до того ж на останньому наголошеному слові голос достатньо різко опускається вниз. Це тон категоричного твердження, завершеності, визначеності.

Спадні тони в обох мовах використовуються у простих розповідних та заперечних реченнях (She was dreaming about her future vacations. I don't want to read this book); вигуках (Oh, no!); фрінальній частині альтернативних запитань (Would you like to try this sponge cake or tiramisu?); другій частині розділових запитань (у тому випадку, коли мовець упевнений у правильності першої частини висловлювання і не чекає ніяких доповнень) (They've been to Italy this summer, haven't they?); спеціальних запитаннях (Where have you been?); привітаннях (Hello!); спонукальних реченнях (Try not to forget this) (Корунець, 2004, р. 103-104).

Зазначимо, що для англійського мовлення характерним $€$ наявність високого початку та різкого падіння у спадному тоні. В українській мові діапазон не $є$ таким широким, що викликає труднощі у засвоєнні учнями цього тону.

У висхідному тоні перший наголошений склад вимовляється на достатньо низькому рівні, а підйом голосу відбувається поступово. Висхідний тон - це тон невпевненості, невизначеності, сумнівів. Висхідні тони використовуються у загальних питаннях (Do you know him?); у вимогах та проханнях (Help me, please, to translate the text); під час переліку (She knows not only English, but also Italian, Turkish and Spanish); для вираження невпевненості, пропозиції, ввічливого запрошення, прохання, застереження (You may stay here); y першій частині альтернативних запитань (яка являє собою загальне запитання) (Are you a student or a pupil?); у завершальній частині розділових запитань, коли мовець не впевнений у правильності першої частини і бажає 
отримати додаткову інформацію (He is clever, isn't he?). Слід зазначити, що в англійській мові прощання вимовляються висхідним тоном (Good bye!), а в українській - спадним (До побачення) (Корунець 2004: 107).

Рівний тон використовується в обох мовах для позначення слів автора після прямої мови («I didn't do this» - he said in a low voice); вставних слів (He can, for example, help us to decorate the living-room); уточнюючих частин речень (There, at my parents', I feel safe) (Kopyнець, 2004, p. 108-109).

Англійська мова характеризується наявністю спадно-висхідного тону, тобто голос спочатку знижується в межах одного складу до найнижчого рівня, а потім поступово підвищується. Цей тон використовується для уточнення (Did he really say that?); дружнього запере- чення (I am afraid that's not so); сумніву (What colour is her dress? It may be grey); здогадки (May be he arrives on Friday); протиставлення (I have a lot of Russian books, but no French books) (Корунець, 2004).

Ми пропонуємо наступні вправи на удосконалення вживання різних типів англійських ядерних тонів.

Вправа 1. Мета: ознайомити учнів з вживанням ядерних тонів на рівні речення. Очікувані результати: учні слухають речення, повторюють за диктором речення, дотримуючись правильної інтонації, потім тренуються у вживанні різних типів ядерних тонів. Вид: некомунікативна, рецептивно-репродуктивна вправа на імітацію. Інструкція: Listen, repeat after the speaker and then practice with your partner various nuclear tones in the following contexts.

\begin{tabular}{|c|c|c|}
\hline $\begin{array}{l}\text { A) The Low Falling Tone } \\
\text { 1. What season is it now? - It's } \\
\text { Summer. } \\
\text { 2. What day is it today? - It's } \\
\text { Tuesday. }\end{array}$ & $\begin{array}{l}\text { B) The High Falling Tone } \\
\text { 1. What's your day off? - 'Sunday. } \\
\text { 2. What's your hobby? - 'Drawing. }\end{array}$ & $\begin{array}{l}\text { C) The Low Rising Tone } \\
\text { 1. Excuse me, may I ask you a } \\
\text { question? - Yes. } \\
\text { 2. Here's your book. - , Thanks. }\end{array}$ \\
\hline $\begin{array}{l}\text { D) The High Rising Tone } \\
\text { 1. Let's meet at seven. } \\
\text { - At the 'theatre? } \\
\text { 2. Let's meet later. } \\
\text { - At 'eight? }\end{array}$ & $\begin{array}{l}\text { E) The Falling-Rising Tone/ The } \\
\text { Falling-Rising Tone Divided } \\
\text { 1. The lesson is interesting. - 'Dull } \\
\text { 2. The lesson begins in ten minutes. } \\
\text { - Hurry , up. }\end{array}$ & $\begin{array}{l}\text { F) The Rising-Falling Tone } \\
\text { 1. He is a talented pianist. - }{ }^{-} \text {Really! } \\
\text { 2. We'll go abroad in June. } \\
\text { - 'How interesting! }\end{array}$ \\
\hline
\end{tabular}

Вправа 2. Мета: фрормувати навичку учнів визначати тони відповідно до прослуханого висловлювання. Очікувані результати: учні визначають тони відповідно до прослуханого висловлювання. Вид: некомунікативна, ре- цептивноа вправа на ідентифікацію ядерного тона. Інструкція: Listen to each word with either Falling, Rising or Level intonation. Write $F$ if you hear a Fall, $R$ if you hear a Rise and $L$ if there is no change in pitch.

\begin{tabular}{|l|l|l|l|}
\hline & Fall & Rise & Level \\
\hline & Uh oh & Uh oh? & Uh oh... \\
\hline & Monday & Monday? & Monday... \\
\hline & Coming & Coming? & Coming... \\
\hline & Later & Later? & Later... \\
\hline & Fifty & Fifty? & Fifty... \\
\hline & What & What? & What... \\
\hline
\end{tabular}

Вправа 3. Мета: формувати навичку учнів у визначенні тонів на рівні речення. Очікувані результати: учні визначають рух висхідного/ низхідного тону, розставляючи відповідні маркери висхідного/низхідного тонів. Вид: некомунікативна вправа. Інструкція: Decide which tone the speakers use for each speech unit. Write the symbol or in each gap. Then show the stressed syllables by underlining them and the nucleus syllable by double underlining them. EXAMPLE: I lost the keys.
1. How was your Journey? 2. Did you have a good journey? 3 . I need to apply for a credit card._4. I'd like an appointment with you.

5. Let's turn off the air conditioner.

Отже, ми розглянули особливості мелодичної складової просодії та представили варіанти вправ для роботи над ядерними тонами. Другим компонентом опишемо тембр.

Тембр розглядається як особливе забарвлення голосу під час мовлення, що накладається на мелодику й показує емоційний стан мовця (радість, сум, іронію, злість, обурення і т. п.). 
За даними проведеного спостереження за учнями старших класів, більшість учнів не володіють, або недостатньо володіють цим компонентом інтонації. 7 з 10 учнів класу майже не могли змінювати власний тембр голосу на прохання вчителя. Завданнями для розвитку тембральних модуляцій голоса можуть стати наступні вправи:

Вправа 4. Мета: формувати навичку володіння учнями тембральними змінами голосу. Очікувані результати: учні можуть змінювати тембр власного голосу за вчителем. Вид: некомунікативна, рецептивно-репродуктивна вправа на імітацію. Інструкція: Pronounce sentences coping the voice of your mother/father, an angree woman/ an angree teacher/ a neutral indifferent speaker.

Вправа 5. Мета: автоматизувати навичку володіння учнями тембральними змінами голосу. Очікувані результати: учні продукують текст, змінюючи тембр голосу. Вид: некомунікативна, рецептивно-репродуктивна вправа на імітацію. Інструкція: Read (Reproduce) the text like the speaker, coping the intonation.

Наступний компонент - наголос. Наголос у реченні (наголос на рівні висловлювання / акцент) - надання одному чи більше словам більшої значущості серед інших слів речення, що виступає силовим компонентом інтонації (Паращук, 2009, р.118).

Слухаючи англійську мову, можна легко відчути, що вона ділиться на окремі ритмічні групи. Характерний ритм англійської мови залежить від розподілу наголошених і ненаголошених складів. Наголошені склади вимовляють із більшою силою, з більшим напруженням м'язів грудної клітини й обличчя. Окремо вимовлені англійські слова завжди мають наголошені склади, проте, в мовленні наголос виділяє лише найважливіші за змістом слова. Особливістю англійського мовленнєвого потока $€$ те, що наголошені склади йдуть один за одним через більш або менш регулярні проміжки часу, незалежно від того, скільки між ними ненаголошених складів (Теоретична..., 2015, р. 91).

Для практичних цілей розрізняють три основних функціональних типи наголосу в реченні: синтагматичний, синтаксичний та логічний. Найбільш важливим функціональним типом є синтагматичний наголос. Разом 3 одним із основних тонів, цей наголос виділяє смисловий центр речення або смислову групу (Антипова, 1985, с. 61). Синтаксичний наголос позначає інші семантично важливі слова у межах висловлювання (там само). Логічний наголос пов'язаний зі зміщенням синтагматичного наголосу з його нормального місця (останне наголошене слово) на одне з попередніх слів. Такий наголос створює новий комунікативний центр (там само).

Зазвичай службові частини мови (артиклі, частки, допоміжні та модальні дієслова, дієслова-зв'язки, прийменники, сполучники артиклі, особові, присвійні та вказівні займенники) переважно не наголошуються у зв'язному мовленні, тоді як повнозначні частини мови (дієслова, іменники, прикметники) можуть бути в реченні як під наголосом, так і без нього (Теоретична..., 2015, с. 91-93). Службові слова можуть бути наголошеними у випадку, якщо вони: 1) займають кінцеве положення в реченні: What are you looking at? 2) використовуються для емфатичного підкреслення: Do you want this one? 3) використовуються для протиставлення та надання контрасту: $\mathrm{He}$ is working hard. She is, but not he (Паращук 2009).

Для опрацювання різних типів наголосу ми пропонуємо виконати наступні вправи.

Вправа 6. Мета: фрормувати навичку учнів у використанні правильного наголосу на рівні словосполучення. Очікувані результати: учні розпізнають наголошенні та ненаголошені слова на рівні словосполучення. Вид: некомунікативна, рецептивна вправа на ідентифікацію. Інструкція: You will hear 15 compound nouns. Write them in the correct columns, according to whether the first, second or third part has the main stress.

\begin{tabular}{|l|l|l|}
\hline main stress on the first part & main stress on the second part & main stress on the third part \\
\hline & & \\
\hline
\end{tabular}

(pinball machine, aircraft carrier, nail varnish remover, payback period, left-luggage office, headed notepaper, car boot sale, level playing field, cooling-off period, first-time buyer, downhill skiing, bullet-proof vest, two-way mirror, righthand drive, household name) (Hewings 2007). 
Вправа 7. Мета: формувати навичку учнів у застосуванні наголосу на рівні слова/ словосполучення. Очікувані результати: учні розпізнають на слух наголошенні склади в словах та слова в словосполученнях. Вид: некомуніка-

selfish

differentiated

decade

attic

one person

homesick (sick for home)

(Judy 2005)

Вправа 8. Мета: формувати навичку учнів у використанні наголосу на рівні речення. Очікувані результати: учні розпізнають головний наголос у реченні. Вид: умовно-комунікативна, рецептивно-репродуктивна вправа на імі- тивна, рецептивна вправа на диференціацію. Інструкція: Listen to the teacher say one of the words from each pair. Put a tick next to the word you hear.

sell fish

different shaded

decayed

a tick

one percent

home sick (sick at home)

тацію. Інструкція: Listen to three dialogues. Pay attention to the pronunciation of main stress in the sentences. Then practice the dialogues with your partner.

\begin{tabular}{|l|l|l|}
\hline A: How long have you been & $\begin{array}{l}\text { A: Why don't you try keeping a } \\
\text { frightened of snakes? }\end{array}$ & $\begin{array}{l}\text { As there anything that really } \\
\text { frightens you ? }\end{array}$ \\
$\begin{array}{l}\text { B: I've always been terrified of } \\
\text { snakes }\end{array}$ & $\begin{array}{l}\text { B: l've always been terrified of of always been terrified of } \\
\text { snakes. }\end{array}$ \\
snakes.
\end{tabular}

(Hewings 2007).

Вправа 9. Мета: фрормувати навичку учнів визначати головний наголос у реченні. Очікувані результати: учні визначають головний наголос у реченні. Вид: некомунікативна, рецептивно-репродуктивна вправа на підста- новку. Інструкція: You have 3 sentences each with 3 different questions. Change the stress as you use the same sentence to answer a different question. Work in pairs.

\begin{tabular}{|l|l|l|}
\hline I am catching a train to work. & Mike's mom is a bright scientist. & I wish I had a Ford. \\
Q1: Why don't you catch a bus to & Q1: Do you know some bright & Q1: Do you have a Ford? Q2: \\
work? Q2: How are you going to & scientist? Q2: Is your dad a bright & Did you say you had a Ford? Q3: \\
get to work? Q3: Where are you & scientist? Q3: What does your & What's your dream car? \\
going? & mom do?
\end{tabular}

Отже, наголос виступає як один із формантів ритмічності мовлення, а також як складова ритму і водночас, як компонент інтонації. Тому наступним компонентом ми розглянемо ритм. А. М. Антипова визначає мовленнєвий ритм як періодичність схожих явищ та явищ, що можуть бути співвіднесеними, і як загальномовленнєву систему, що організує мову в цілому (Антипова, 1990). Англійський фонетист М. Ламсден наголошує на необхідності першочергового вивчення ритму, бо саме ритм видає неанглійське походження учня (Lumsden, 1957).

В англійській мові наголошені склади зустрічаються через однакові відрізки часу у зв'язному мовленні. Чим більше ненаголошених складів знаходиться між наголошеними, тим слабше і швидше вони вимовляються. Ненаголошені склади, котрі передують наголошеному, носять назву проклітиків, а ті, що слідують за наголошеним, - енклітиків. При цьому проклітики зазвичай вимовляються дуже швидко, а голосні звуки в них ослаблюються, наприклад: He was at work. У наведеному прикладі наголошеним $є$ останній склад, а відповідно ті, що передують йому, втрачають свою силу. Зі смислової точки зору, адресант більше зацікавлений у тому, де саме знаходився суб'єкт, про який ідеться (Паращук, 2009).

В англійській мові існують наступні правила ритму, так: 1) Наголошені склади в смисловій групі слідують один за одним через однакові проміжки часу; тільки в дуже довгих ритмічних групах, що мають велику кількість ненаго- 
лошених складів, така регулярність може не спостерігатись. 2) Більшість непочаткових ритмічних груп починаються з наголошеного складу; ненаголошені склади, що зустрічаються в середині групи, мають тенденцію відходити до передуючого ним наголошеного складу - енклітики, тільки початкові ненаголошені склади відносяться до наступного за ними наголошеного складу - проклітики. 3) Чим більша кількість ненаголошених складів знаходиться між наголошеними, тим швидше вони вимовляються. Початкові ненаголошені склади завжди вимовляються швидко. Кожна смислова група має власний ритм, залежно від наданої їй семантичної важливості в порівнянні з іншими групами висловлення (Антипова, 1990).

Говорячи про інтонаційні особливості англійської та української мов, необхідно пам'ятати, що в українському реченні всі основні частини мови (а також дуже часто і службові частини мови) наголошені. В англійському ж реченні тільки основні частини мови (за виключенням більшості займенників) мають наголос. Службові частини мови можуть набувати логічного наголосу. Саме наголошення службових слів, модальних і допоміжних дієслів, особових і присвійних займенників є типовими помилками україномовних студентів, які вивчають англійську мову. Наслідком цього $є$ грубе порушення ритмічної організації мовлення, втрата специфрічної для англійської вимови чіткої ритмічної структури мовлення з більш-менш рівними інтервалами між наголошеними словами в реченні (Антипова 1980).

В англійському реченні без наголосу вимовляються: допоміжні дієслова, дієслова зв'язки (be, get, turn тощо), модальні дієслова, прийменники (on, to, in, in front of тощо), сполучники (and, but, or, both тощо), особисті та присвійні займенники (I, me, his, her, it тощо).

Пропонуємо наступні вправи.

Вправа 10. Мета: ознайомити учнів 3 англійським ритмом. Очікувані результати: учні практикують ритмічну вимову на рівні фррази/ речення. Вид: некомунікативна, рецептив- но-репродуктивна вправа на імітацію. Інструкція: Listen to this lengthening sentence. Note the intonation curve at the end of each phrase or statement. Practice the lengthening sentence.

An 'evening. A 'misty 'evening. A ' misty 'moisty 'evening. A 'misty 'moisty and 'cloudy 'evening. A ' misty 'moisty and 'cloudy un 'pleasant 'evening. A 'misty 'moisty and 'cloudy un'pleasant 'winter 'evening.

Вправа 11. Мета: удосконалити навички ритмічної вимови учнів. Очікувані результати: учні створюють ритмічні групи на рівні речення. Вид: продуктивна вправа на самостійне вживання. Інструкція: Build up with your partner lenghtening sentences, phrase by phrase. Then say them aloud. Possible beginnings are:

A coach. A noisy coach... An apple. A green journey... A film. An interesting film...

3 поняттям ритму пов'язана паузація (speech unit boundaries). Паузи сприяють більш чіткому вираженню думки, не тільки в кінці, але й усередині речення, особливо в довгих реченнях. Оскільки між словами в реченні встановлюються міцні смислові та синтаксичні зв'язки, що було описано вище, паузи не можна робити в довільному місці. Довжина паузи та її місце надають реченню той чи інший смисл. У разі порушення цих зв'язків порушується і смисл речення як одиниці комунікативного спілкування (Теоретична..., 2015).

3 власного досвіду варто додати, що правильна паузація говорить також про розуміння учнем тексту. Звичайно, що невірна паузація здебільшого проявляється в читанні, проте в продукуванні текстів, особливо вивчених на пам'ять, зустрічається також. Отже, для опрацювання навичок паузації пропонуємо наступні вправи.

Вправа 12. Мета: формувати рецептивні навички паузації. Очікувані результати: учні розпізнають різні варіанти пауз у реченні. Вид: некомунікативна, рецептивна вправа на впізнавання. Інструкція: You will hear each messages 1-5 twice. Listen and write the order you hear the different meanings, $A$ and $B$. Then say both messages aloud.

\begin{tabular}{|c|c|c|}
\hline $1 \ldots \ldots \ldots \ldots \ldots \ldots$ & $2 \ldots \ldots \ldots \ldots \ldots \ldots$ & $\ldots$ \\
\hline & A & $B$ \\
\hline whole sentence & You know. The answer's easy. & You know the answer's easy. \\
\hline relative clause & The boy who was clever won. & The boy, who was clever, won. \\
\hline items in a list & Apple juice and biscuits. & Apple, juice and biscuits. \\
\hline Quoting & 'Who?' asked her brother. & Who asked her brother? \\
\hline adverb phrase & I saw her clearly. She was surprised. & I saw her. Clearly, she was surprised. \\
\hline
\end{tabular}

(Hancock 2015) 
Вправа 13. Мета: формувати навичку паузації. Очікувані результати: учні розставляють паузи у реченні. Вид: умовно-комунікативна, продуктивна вправа. Інструкція: In the following sentences underline the speech unit boundary (marked with //) that is more likely. Then say these sentences aloud.

EXAMPLE The only school // that teaches psychology statistics // is to move next year.

1. The ship was launched // in September 1942 // and destroyed a month later.

2. The bird is often heard // but seldom // seen in the wild.

3. Thieves made off // with the painting // despite security guards in the building.
4. Most people also speak German // which is taught // from the age of six.

5. He claimed // he was innocent // but the jury disagreed. (Hewings 2007)

Вправа 14. Мета: фрормувати навичку паузації на рівні тексту. Очікувані результати: учні розставляють паузи у тексті, потім продукують подібний текст, дотримуючись правильної паузації. Вид: комунікативна, продуктивна вправа. Інструкція: Read the text and put speech unit boundaries (marked with //). Then using this text prepare a short speech on the awareness of science among public.

We have a great opportunity//at the moment// to encourage awareness of science// among the public the public continue to see science as important the UK public continue to see science as beneficial to society four-fifths $(81 \%)$ agree that science will make people's lives easier and over half $(55 \%)$ think that the benefits of science outweigh any harmful effects very few $(16 \%)$ disagree with this latter point of view people are positive about the contribution science to the UK economy for example three-quarters $(76 \%)$ think scientific research makes a direct contribution to economic growth in the UK, and nine-in-ten (91\%) agree that young people's interest in science is essential for our future prosperity

(Adapted from Public Attitudes to Science 2014, 2014. http://www.ipsos-mori.com/pas2014)

Висновки. Узагальнимо основні ідеї щодо особливостей просодичної складової англійського мовлення учнів старших класів загальноосвітніх навчальних закладів. Отже, існує багато поглядів щодо просодії та інтонації, вчені фактично ототожнюють компоненти інтонації, які представлені складним комплексом просодичних елементів, із просодією, яка виявляється у рівні володіння мовцем паузацією, мелодикою, наголошенням, злитістю наголошених і ненаголошених складів у ритміко-інтонаційній групі, темпом мовлення й забезпечує сприйняття та розуміння зверненого мовлення. Зверотаючи увагу на певні розходження між просодичними системами англійської та української мов, ми запропонували комплекс вправ для удосконалення володіння просодичною складовою англійського мовлення учнів старших класів.

Перспективи дослідження. Просодія на сьогодні $є$ актуальним предметом дослідження. Розроблені завдання та вправи потрібно розширювати пілотувати та модифікувати 3 метою удосконалення опрацювання просодичного компонента учнями старшої школи у навчальному процесі. Це віднесемо до подальшого наукового осмислення і практичного втілення.

\section{References}

Crystal, D. (2003). The Cambridge Encyclopedia of the English Language: 2-nd edition. Cambridge: CUP.

Hancock M. (2015). English Pronunciation in Use Intermediate. Second Edition. Cambridge: CUP.

Hewings, M. (2007). English pronunciation in use. Advanced. Cambridge: CUP.

Judy G. B. (2005). Clear Speech. Cambridge: CUP.

Kingdom, K. (1958). The Groundwork of English Intonation. London.

Lumsden, M. (1957). English Speech Rhythm in Theory and Practice. London: Macmillan St. Martin's press.

Roach P. (2012). English phonetics and phonology. 4th edition. Cambridge: CUP.

Антипова, А. М. О ритме английской речи. Иностранные языки в школе. 1990. № 2. С. 5560. (Antipova, A. M. O ritme angliyskoy rechi (1990). Inostrannyye yazyki v shkole. № 2. S. 55-60).

Антипова, А. М. Ритмическая организация английской речи : дис. на соискание наук. степени докт. филолог. наук. Москва, 1980. 447 c. (Antipova, A. M. (1980). Ritmicheskaya organizatsiya angliyskoy rechi: Dis. na Soiskaniye nauk. stepeni dokt. filolog. nauk. Moskva). 